\title{
RANCANG BANGUN APLIKASI SIMPAN PINJAM PADA KOPERASI SAMI BERBASIS WEB
}

\author{
Maimunah $^{1}$ \\ Devi Isnaeni ${ }^{2}$ \\ Ade Ferdiansyah $^{3}$ \\ Dosen Tetap STMIK Raharja ${ }^{1}$,Mahasiswa STMIK Raharja Jurusan Sistem Informasi ${ }^{3}$ \\ Jl. Jendral Sudirman No 40, Modernland Tangerang $1,2,3$ \\ email : maimunah@raharja.info ${ }^{1}$, deviisnaeni@yahoo.co.id ${ }^{2}$, ade.ferdiansyah@ @aharja.info ${ }^{3}$
}

\begin{abstract}
Cooperative Ardhia Satya Mandiri ( KOSAMI ) requires good data processing system and integrated in order to facilitate the decision-making and create a good standard of service. Moreover, if the data associated with the financial and customer. Data and information is easily accessible by the Cooperative Ardhia Satya Mandiri ( KOSAMI ), employees , and customers are needed to support the performance of the cooperative in question. This study discusses the application of savings and credit program consisting of members of the input form, the form of borrowing, payment form, the form member, and payment reports . The programming language used to program these applications is the PHP programming language and the SQL Server database. This research was made through through the stages of ( 1 ) identification, ie identifying the problem, ( 2 ) Understand, understand the working of the existing system, ( 3 ) analysis, which analyzes the system, ( 4 ) Report, which report the results of the analysis .
\end{abstract}

Keywords : application program, savings and loans, cooperative

\begin{abstract}
ABSTRAK
Koperasi SAMI memerlukan sistem pengolahan data yang baik dan terpadu guna memudahkan dalam pengambilan keputusan dan menciptakan standar pelayanan yang baik. Apalagi jika data tersebut berhubungan dengan keuangan dan nasabah. Data dan informasi yang mudah diakses oleh Koperasi Satya Ardhia Mandiri (KOSAMI), karyawan, dan nasabah sangat dibutuhkan guna mendukung kinerja dari koperasi yang bersangkutan. Penelitian ini membahas mengenai program aplikasi simpan pinjam yang terdiri dari form input anggota, form peminjaman, form pembayaran, form anggota, dan laporan pembayaran. Bahasa pemrograman yang digunakan untuk program aplikasi ini adalah bahasa pemrograman PHP dan dengan database SQL Server. Penelitian ini dibuat melalui melalui tahap-tahap (1) Identifikasi, yaitu mengidentifikasi masalah, (2) Understand, yaitu memahami kerja dari sistem yang ada, (3) Analisa, yaitu menganalisis sistem, (4) Report, yaitu membuat laporan hasil analisis.
\end{abstract}

Kata kunci : program aplikasi, simpan pinjam, koperasi

\section{Pendahuluan}

Sebagian besar masyarakat sudah tidak asing lagi dengan teknologi komputer, banyak aplikasiaplikasi baru yang menarik khusus diciptakan oleh para programer untuk memuaskan para pengguna komputer.

Diera globalisasi sekarang ini komputer memiliki banyak fungsi dalam berbagai bidang, seperti bidang industri, pendidikan, perdagangan, pemerintahan, pertanian, peternakan dan lain sebagainya. 
Informasi adalah salah satu kunci pada saat ini, semua kegiatan kita memerlukan informasi, dan bisa juga dikatakan bahwa semua kegiatan kita dituntut untuk menghasilkan informasi. Untuk mendapatkan dan menghasilkan informasi, komputer dan teknologinya adalah salah satu alat bantu yang paling tepat. Penggunaan komputer pada berbagai bidang, kalangan dan usia selalu kita jumpai sekarang ini. Tuntutan kebutuhan akan informasi dan penggunaan komputer yang semakin banyak mendorong terbentuknya sebuah jaringan komputer yang mampu melayani berbagai kebutuhan tertentu. Dengan adanya jaringan komputer, pengelolaan informasi dapat berlangsung lebih baik lagi. Berkembangnya teknologi dan kebutuhan akan informasi menyebabkan bertambah kompleksnya informasi yang harus dan yang bisa diolah, sehingga kebutuhan penggunaan beberapa jaringan komputer bersama-sama semakin diperlukan. Penggunaan jaringan secara bersama-sama ini membentuk jaringan komputer yang amat besar yang tersebar di seluruh bagian muka bumi ini.

Dalam sistem simpan pinjam pada Koperasi Satya Ardhia Mandiri (KOSAMI) masih menggunakan sistem manual sehingga sering terjadi keterlambatan data atau laporan. Dengan sistem manual tersebut banyak sekali kelemahan atau kekurangan pada sistem pengolahan data-datanya, diantaranya adalah datanya tidak up to date, data tidak tepat, banyak data yang tidak beraturan/terorganisir atau hilang, rusak dan laporan menjadi lambat.

Dengan sistem komputerisasi diharapkan semua kelemahan yang ada bisa tertutupi atau terminimalisir dengan baik. Sistem komputerisasi akan sangat diperlukan dan akan sangat membantu dalam proses simpan pinjam pada Koperasi Satya Ardhia Mandiri (KOSAMI). Oleh karena itu, sistem komputerisasi sangat dibutuhkan guna meringankan dan mengefektifkan kinerja di Koperasi Satya Ardhia Mandiri (KOSAMI).

\section{Perumusan Masalah}

Berdasarkan latar belakang diatas, maka peneliti merumuskan masalah dalam penelitian ini adalah Bagaimana membangun aplikasi simpan pinjam pada koperasi SAMI berbasis WEB

\section{Literature review}

1. Penelitian ini dilakukan oleh Muhammad Nashir dan Ahmad Riyadi dari Universitas PGRI Jogyakarta. Penelitian ini berjudul Sistem Administrasi Koperasi Simpan Pinjam Kopkar Sejahtera upy menggunakan multi interface. Penelitian ini membahas mengenai bagaimana membangun aplikasi sistem untuk membantu dalam pencatatan dan perhitungan transaksi keuangan secara terkomputerisasi. Penelitian ini berisi program yang meliputi Daftar Anggota, Simpanan, Pinjaman, Angsuran dan Laporan. Pembuatan aplikasi ini menggunakan beberapa perangkat lunak pendukung seperti Mozilla Firefox sebagai web browser,bahasa pemrograman VB dan PHP, Macromedia Dreamweaver, Accsess.

2. Penelitian ini dilakukan oleh Ratih Yunita, Jemakmun dan Baibul Tujni dari Universitas Bina Darma. Penelitian ini berjudul Rancang bangun sistem informasi simpan pinjam pada koperasi ganesa indah balai konservasi sumber daya alam (ksda) sum-sel dengan menggunakan metode prototyping. Penelitian ini membahas mengenai rancang bangun sistem informasi simpan pinjam dengan menggunakan pemrograman $P H P$ dan MYSQL. Penelitian ini berisi sistem informasi ynag digunakan untuk mengolah data anggota, data simpan, data pinjam dan data angsuran

3. Penelitian ini dilakukan oleh Citra Maulana dari Universitas Gunadarma. Penelitian ini berjudul Rancang Bangun Informasi Penjualan dan Simpan Pinjam pada Koperasi Pegawai Mahkamah Agung Jakarta. Penelitian ini membahas mengenai Rancang Bangun Informasi Penjualan dan Simpan Pinjam dengan menggunakan metode DFD (Data Flow Diagram) sebagai alat bantu dalam penggambaran model jalannya sistem, ERD (Entity Relationship Diagram) untuk pembuatan model jaringan, struktur-struktur serta relationship serta Visual Basic 6 untuk perancangan sistem

4. Penelitian ini dilakukan oleh Edi Wibowo dari STMIK AMIKOM Yogyakarta. Penelitian ini berjudul Rancang Bangun Sistem Pengoalahan Data Simpan Pinjam Koperasi. Penelitian ini membahas 
mengenai sistem pengolahan data simpan pinjam, pembayaran angsuran dan pengolahan data anggota koperasi. Aplikasi yang digunakan untuk menjalankan program ini adalah Netbeans J2SE 6.9 dan mysql server sebagai database.

5. Penelitian yang dilakukan oleh Fatimah Hapsah Harahap, Anak Agung Gde Agung dan Sendi Gusnandar Arnan dari Politeknik Telkom Bandung. Penelitian ini berjudul Aplikasi Simpan Pinjam Berbasis Web. Penelitian ini membahas mengenai aplikasi simpan pinjam berbasis web dengan teknik pemrograman terstruktur, menggunakan bahasa pemrograman PHP dan MYSQL. Aplikasi ini disediakan untuk memberikan kemudahan menyampaikan informasi dari pengurus ke anggota mengenai proses simpan pinjam anggota, dan keakuratan dalam melaksanakan pengolahan data simpan pinjam agar medapatkan hasil yang optimal.

6. Penelitian ini dilakukan oleh Agung Prasetyawan, Kodrat Iman Satoto dan Adian Fatchur Rochim dari Universitas Diponegoro. Penelitian ini berjudul Perancangan Sistem Informasi Simpan Pinjam Koperasi Pegawai Republik Indonesia Universitas Diponegoro Berbasis Web. Penelitian ini membahas mengenai sistem informasi koperasi, proses pengajuan sistem pinjam, proses pengelolaan simpan pinjam dan cetak bukti simpan pinjam.

\section{Metode Penelitian}

Metode yang digunakan dalam penelitian ini adalah metode deskriptif yang merupakan penelitian yang berusaha menggambarkan secara sistematis fakta dan karakteristik objek atau subjek yang diteliti secara tepat.

\section{Desain Sistem \\ Use Case Diagram}

Diagram use case digunakan untuk memperlihatkan hubungan-hubungan yang terjadi antara aktoraktor dengan use case-use case yang ada dalam sistem, sehingga calon penguna sistem/perangkat lunak mendapatkan pemahaman tentang sistem yang akan dikembangkan. 


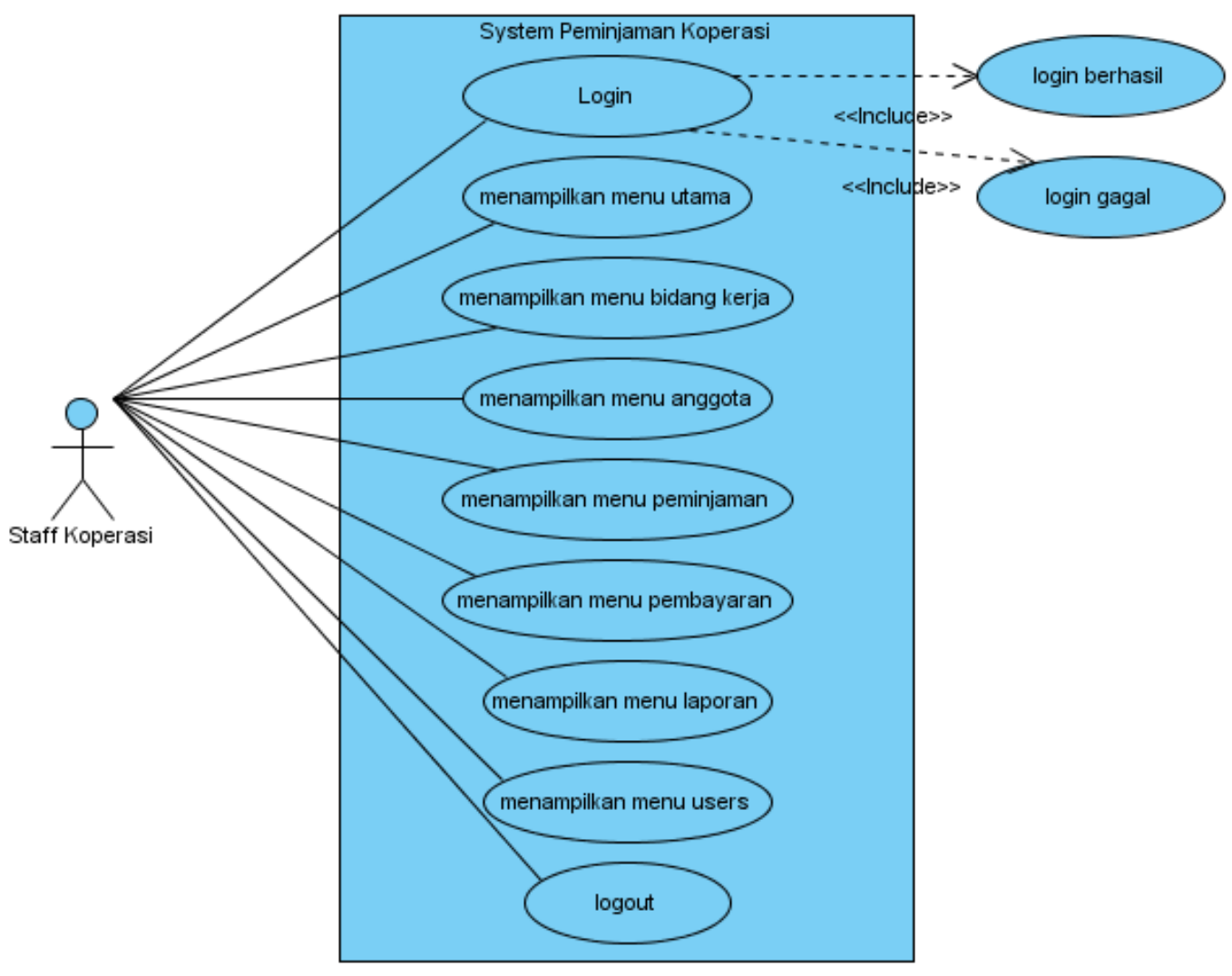

Gambar 1. Use Case Diagram

Pada gambar 3 use case diagram, terdapat 1 actor yaitu staff koperasi dan ada 9 use case yang dilakukan oleh actor tersebut.

\section{Activity Diagram}

Activity diagram menggambarkan berbagai alur aktivitas dalam sistem yang dirancang, bagaimana masing-masing alir berawal, decision yang mungkin terjadi, dan bagaimana mereka berakhir. Activity diagram juga dapat menggambarkan proses paralel yang mungkin terjadi pada beberapa eksekusi. 


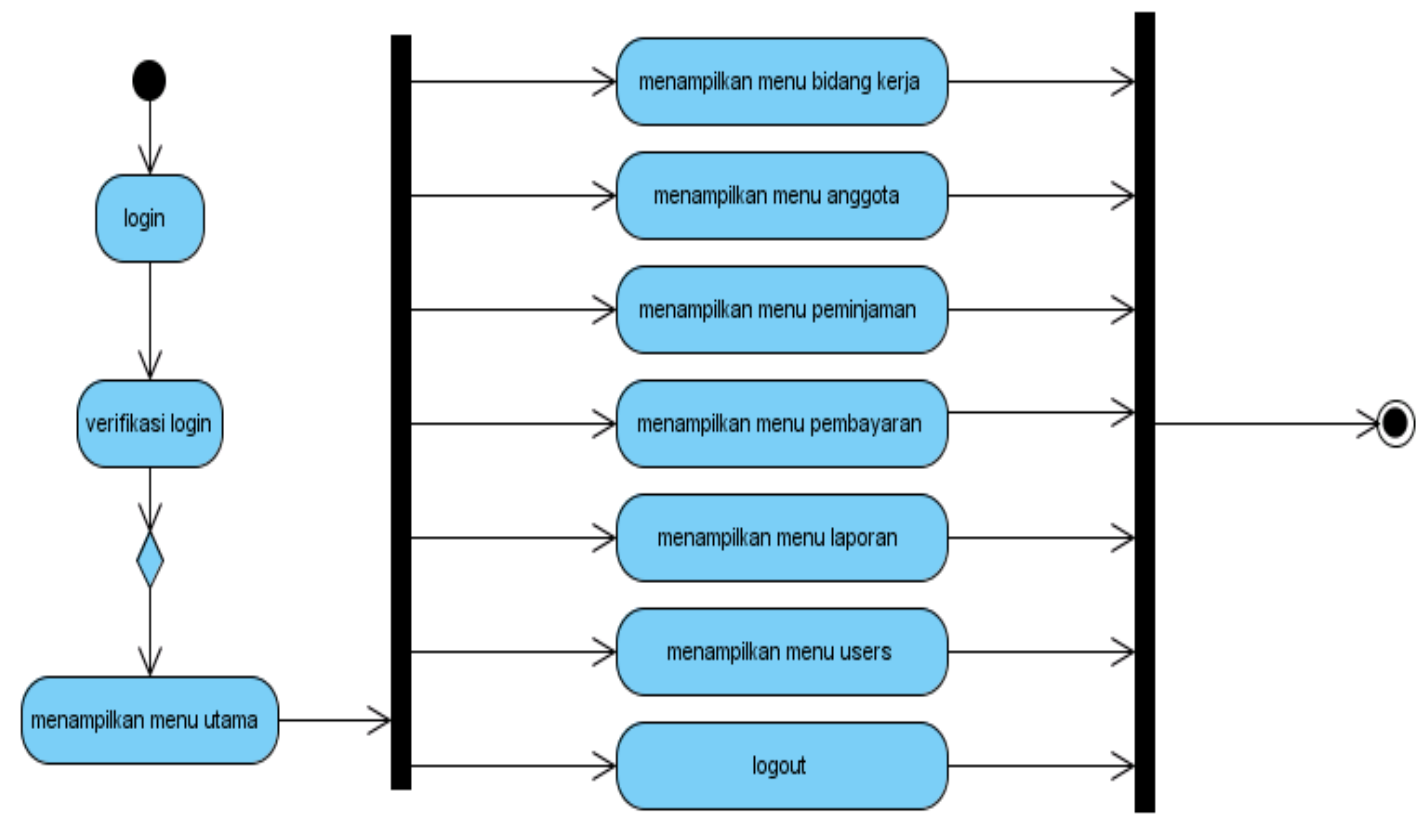

Gambar 2. Activity Diagram

Pada gambar 2 activity diagram, terdapat 10 action yang mencerminkan eksekusi dari suatu aksi dan 2 fork node yaitu satu aliran yang pada tahap tertentu berubah menjadi beberapa aliran.

\section{Class Diagram}

Class Diagram merupakan diagram yang digunakan untuk menampilkan beberapa kelas serta paketpaket dalam sistem. 


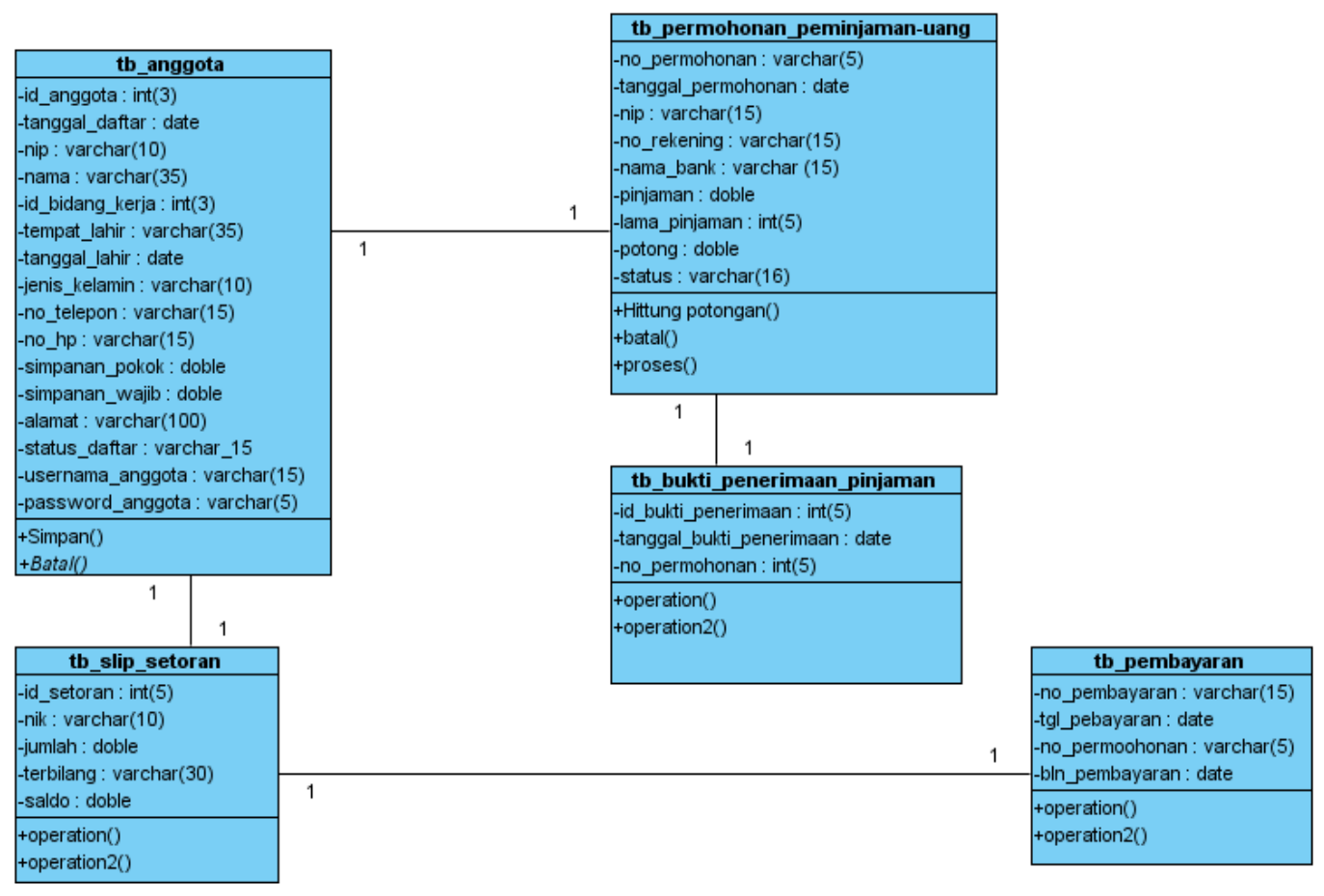

Gambar 3. Class Diagram

Pada gambar 3 class diagram, terdapat 5 class yang merupakan himpunan dari objek-objek yang berbagi atribut serta operasim yang sama dan 4 association yang digunakan untuk memodelkan relasi di antara

\section{Implementasi}

\section{a. Tampilan Menu Login Admin}

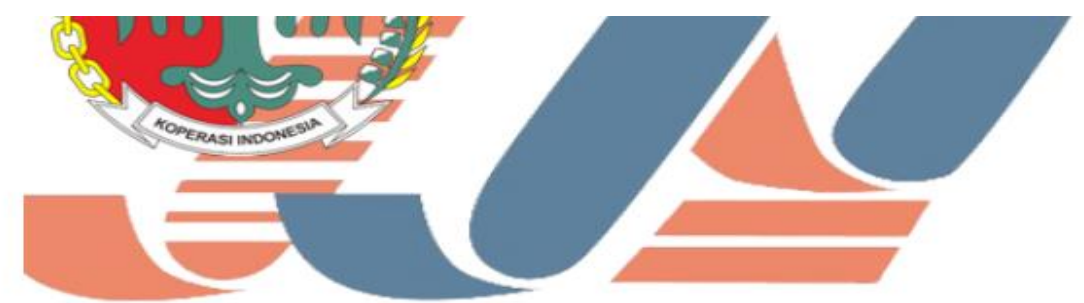

Minggu 16 Desember

2013 Outbound

Activities (Ledok

Sambi Village), Biaya

Pendaftaran Anggota

Koperasi Satya Ardhia

Mandiri 70.000, Pelajar

\section{Koperasi Satya Ardhia Mandiri (KOSAMI)}

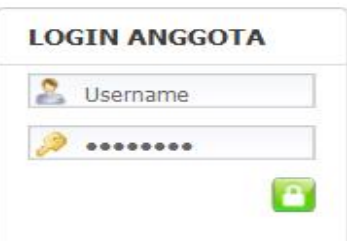

(.) -

Silahkan login terlebih dahulu.....

Username :

Password

Login

Gambar 4. Tampilan Menu Login Admin 
Pada gambar 4 tampilan menu login admin merupakan login yang dapat di akses oleh Admin yang telah memiliki hak akses untuk menggunakan system tersebut. Jika seorang user ingin masuk ke dalam system tersebut, terlebih dahulu harus menginputkan User dan Password yang telah dimiliki sebagai kata kunci untuk masuk kedalam Sistem tersebut. Namum jika Username dan Password yang diinputkan salah, maka akan muncul keterangan yang menyatakan bahwa yang telah di inputkan tersebut salah.

\section{b. Tampilan Menu Utama}

\begin{tabular}{|l|l|l|l|l|l|l|l|}
\hline BERITA & BIDANG KERJA & ANGGOTA & PEMINJAMAN & PEMBAYARAN & LAPORAN & USERS & LOGOUT
\end{tabular}

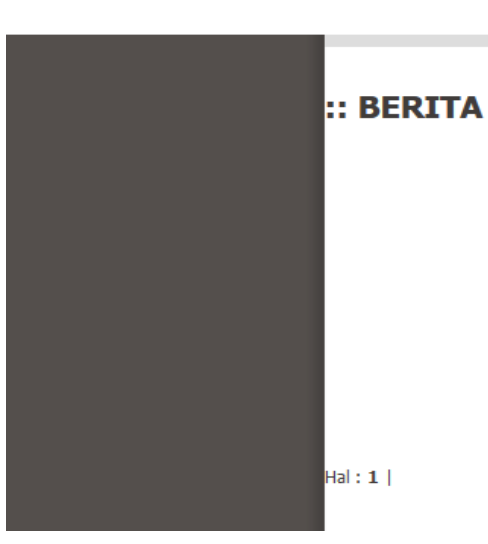

Hello, You are : Administrator

\begin{tabular}{|c|c|c|c|c|}
\hline \multicolumn{3}{|l|}{ Tambah Data Berita } \\
\hline No & Judul & Isi Berita & Edit & Hapus \\
\hline \multicolumn{2}{|l|}{ Database Berita } & $\begin{array}{c}\text { Undangan } \\
\text { Silahturahmi } \\
\text { Angota Koperasi } \\
\text { KOSAMI }\end{array}$ & $\begin{array}{c}\text { Mengundang kepada seluruh Anggota koperasi KOSAMI untuk } \\
\text { dapat hadir dalam acara Silahturahmi pada tanggal 1 Juni 2013 } \\
\text { pukul 12:00 s.d selesai, bertempat di Restauran Padang Gedung } \\
\text { M601 - Bandara Soekarno Hatta Atas perhatiannya kami ucapkan } \\
\text { Terima Kasih Pengurus. Ketua Koperasi Bpk. Asmuno Brawijaya }\end{array}$ & X \\
\hline
\end{tabular}

\section{Gambar 5. Tampilan Menu Utama}

Pada gambar 5 tampilan menu utama merupakan tampilan awal dari system yang terdiri dari Menu Berita, Menu Bidang Kerja, Menu Anggota, Menu Peminjaman, Menu Pembayaran, Menu Laporan, Menu User untuk yang telah memperoleh hak akses.

\section{c. Tampilan Menu Bidang Kerja}

\section{\begin{tabular}{|l|l|l|l|l|l|l|l|}
\hline BERITA & BIDANG KERJA & ANGGOTA & PEMINJAMAN & PEMBAYARAN & LAPORAN & USERS & LOGOUT \\
\hline
\end{tabular}}

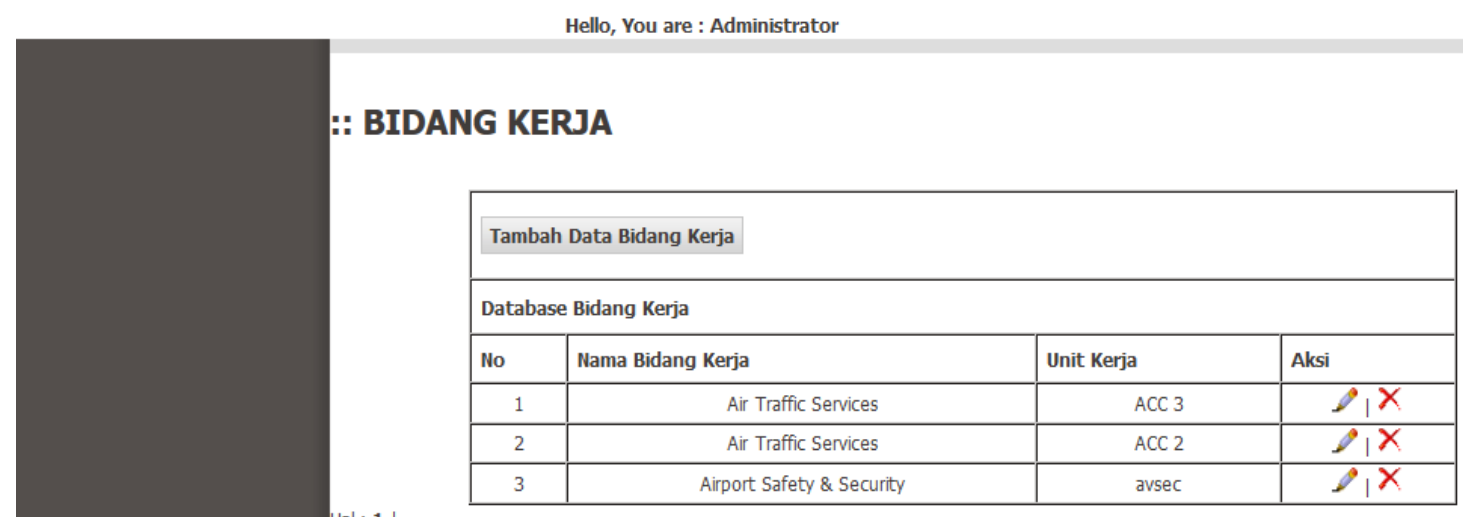

\section{Gambar 6. Tampilan Menu Bidang Kerja}


Pada gambar 6 tampilan menu bidang kerja ini digunakan oleh Admin untuk menginput data bidang kerja anggota koperasi yang terdiri dari field : tambah bidang kerja, no, nama bidang kerja, aksi. Setelah data selesai di input maka admin mengklik tombol simpan untuk menyimpan data bidang kerja anggota yang telah ditambah oleh admin, maka data-data tersebut akan tersimpan didalam database.

\section{d. Tampilan Menu Anggota}

\begin{tabular}{|l|l|l|l|l|l|l|l}
\hline BERITA & BIDANG KERJA & ANGGOTA & PEMINJAMAN & PEMBAYARAN & LAPORAN & USERS & LOGOUT \\
\hline
\end{tabular}

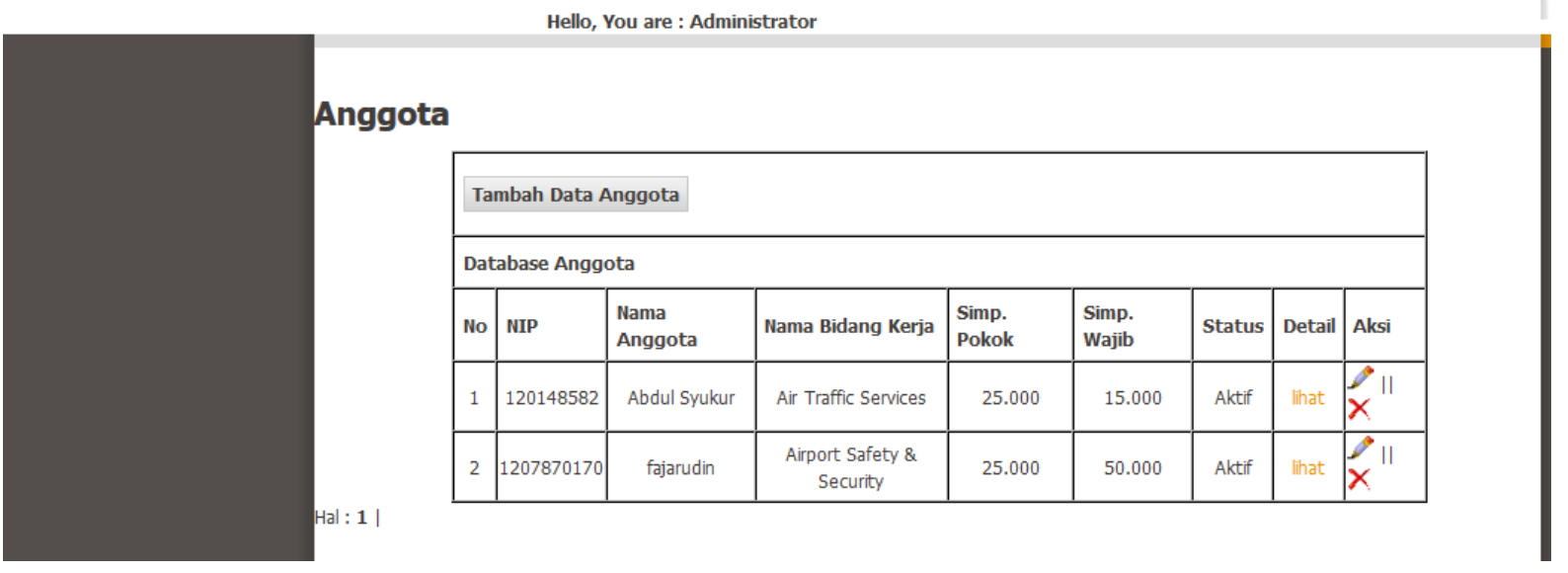

\section{Gambar 7. Tampilan Menu Anggota}

Pada gambar 7 tampilan menu anggota ini digunakan oleh Admin untuk menginput data anggota koperasi yang terdiri dari field: tambah data anggota, no, nip, nama anggota, nama bidang kerja, simpanan pokok, simpanan wajib, status, detail, aksi. Setelah data selesai di input maka admin mengklik tombol simpan untuk menyimpan data anggota baru yang telah ditambah oleh admin, maka data-data tersebut akan tersimpan didalam database.

\section{e. Tampilan Menu Peminjaman}

\begin{tabular}{|l|l|l|l|l|l|l|l}
\hline BERITA & BIDANG KERJA & ANGGOTA & PEMINJAMAN & PEMBAYARAN & LAPORAN & USERS & LOGOUT
\end{tabular}

Hello, You are : Administrator

\section{:: Daftar Peminjaman}

\begin{tabular}{|c|c|c|c|c|c|c|c|c|}
\hline \multicolumn{9}{|c|}{ Database Peminjaman } \\
\hline No & No Peminjaman & Tanggal & Nip & Nama & Pinjam (Rp.) & Lama Pinjaman & Status & Approval \\
\hline 1 & 00002 & 19 Juni 2013 & 1207870170 & fajarudin & 5.000 .000 & 12 Bulan & Di Setujui & Setujui | di Tolak \\
\hline 2 & 00001 & 15 Juni 2013 & 120148582 & Abdul Syukur & 2.000 .000 & 6 Bulan & Di Setujui & Setujui | di Tolak \\
\hline
\end{tabular}

Gambar 8. Tampilan Menu Peminjaman 
Pada gambar 8 Tampilan menu peminjaman ini digunakan oleh Admin untuk melihat siapa saja anggota koperasi yang akan mengajukan pinjaman ke koperasi. data peminjaman anggota koperasi yang terdiri dari field: no, no pinjaman, tanggal, nip, nama, pinjam, lama pinjaman, status, approval.

\section{f. Tampilan Menu pembayaran}

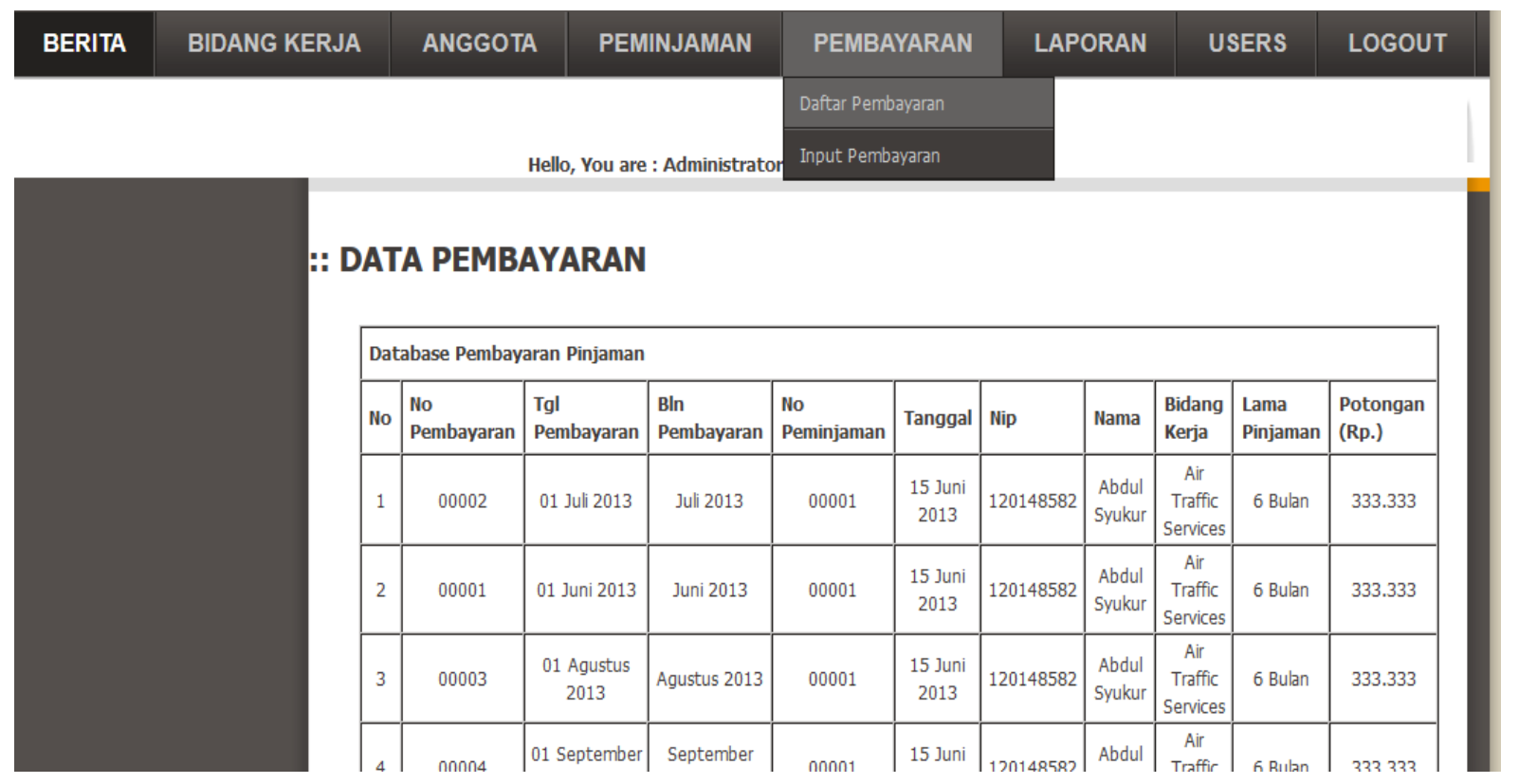

\section{Gambar 9. Tampilan Menu Pembayaran}

Pada gambar 9 tampilan menu pembayaran ini digunakan oleh Admin untuk menginput data pembayaran dan melihat data pembayaran anggota koperasi untuk input pembayaran terdiri dari field: data peminjaman, pilih nip dan nama data peminjaman yang akan membayar. Setelah data selesai di input maka admin mengklik tombol simpan untuk menyimpan data pembayaran anggota dan data yang telah diinput oleh admin akan tampil didaftar pembayaran, maka data-data tersebut akan tersimpan didalam database.

\section{g. Tampilan Menu Laporan}

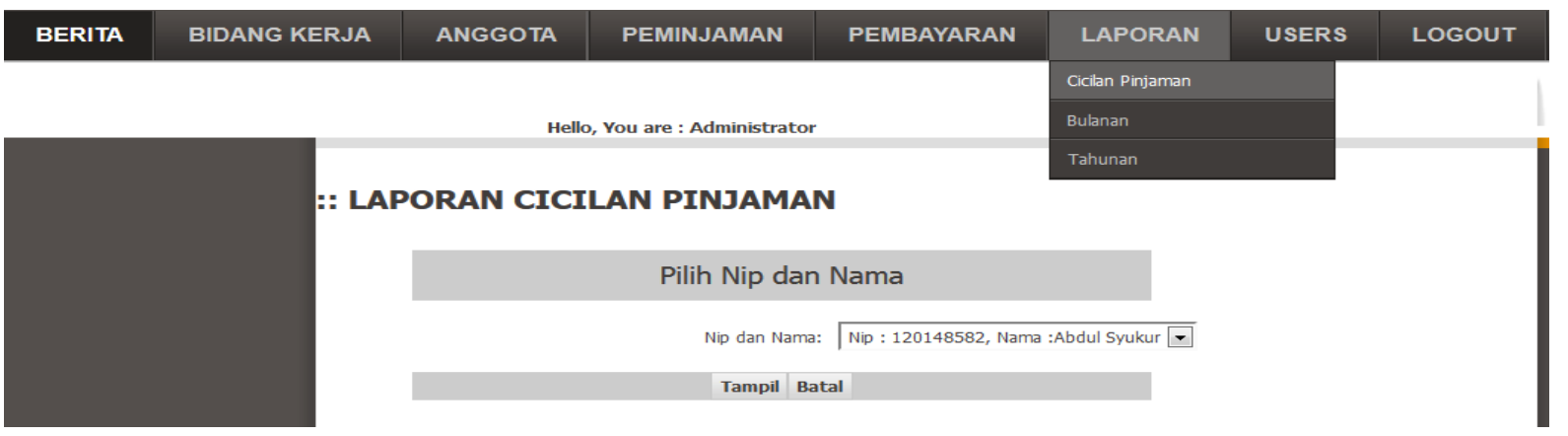

Gambar 10. Tampilan Menu Laporan 
Pada gambar 10 tampilan menu laporan ini digunakan oleh Admin untuk melihat data anggota koperasi dalam bentuk Laporan Pinjaman yang terdiri dari field: laporan cicilan pinjaman, laporan bulanan, laporan tahunan. Yang tersimpan didalam database.

\section{h. Tampilan Menu Users}

\section{\begin{tabular}{|l|l|l|l|l|l|l|l}
\hline BERITA & BIDANG KERJA & ANGGOTA & PEMINJAMAN & PEMBAYARAN & LAPORAN & USERS & LOGOUT \\
\hline
\end{tabular}}

Hello, You are : Administrator

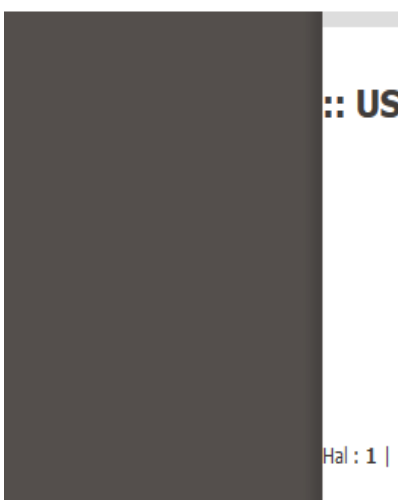

\begin{tabular}{|l|l|l|l|}
\hline \multicolumn{2}{|l|}{ Tambah Data users } \\
\hline \multicolumn{2}{|l|}{ Database users } \\
\hline No & Username & Level & Aksi \\
\hline 1 & admin & Administrator & \\
\hline
\end{tabular}

Gambar 11. Tampilan Menu Users

Pada gambar 11 tampilan menu users ini digunakan oleh Admin untuk menambah users admin yang baru.

\section{i. Tampilan Menu Login Anggota}

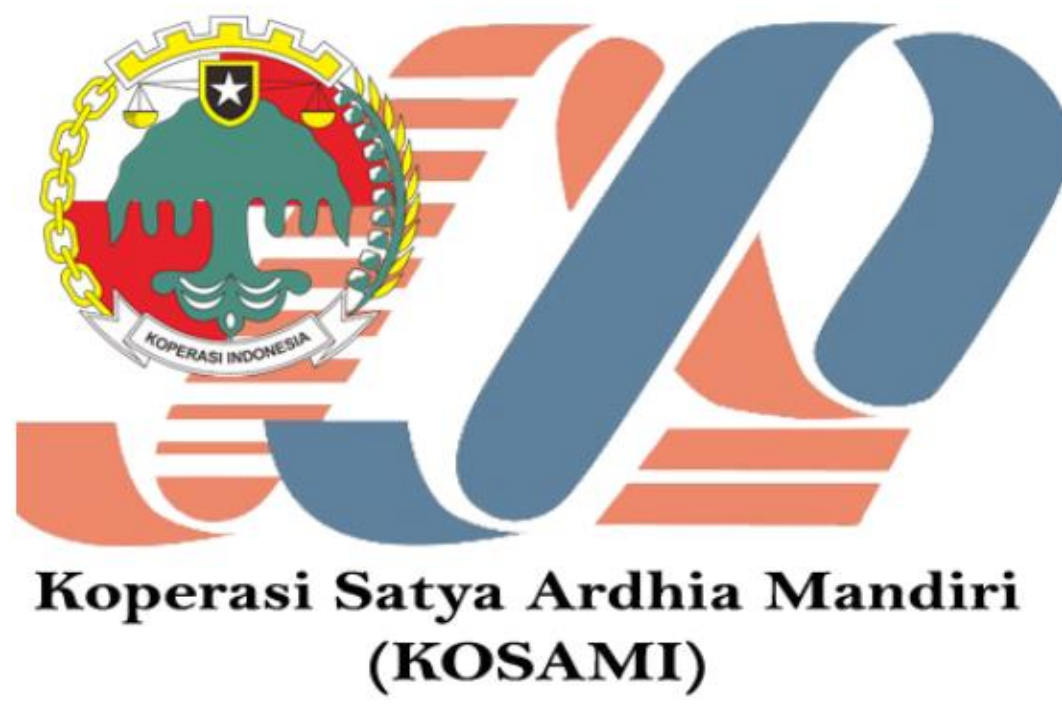

Selt Development

Training "Challenge

Your Self to Change

The World" yang

diadakan oleh Trainer

Community (TC)

Koperasi Satya Ardhia

Mandiri (KOSAMI),

Tanggal Pelaksanaan

Sabtu 15 Desember

2013 di Auditorium

G-100 Bandara

- . $\quad .$.

\section{LOGIN ANGGOTA}

\& abdu

$\bullet$

\section{Gambar 12. Tampilan Menu Login Anggota}


Pada gambar 12 tampilan menu login anggota ini merupakan login yang dapat di akses oleh Anggota yang telah memiliki hak akses untuk menggunakan system tersebut. Jika seorang user ingin masuk ke dalam system tersebut, terlebih dahulu harus menginputkan User dan Password yang telah dimiliki sebagai kata kunci untuk masuk kedalam Sistem tersebut. Namum jika Username dan Password yang diinputkan salah, maka akan muncul keterangan yang menyatakan bahwa yang telah di inputkan tersebut salah.

\section{j. Tampilan Menu Keanggotaan}

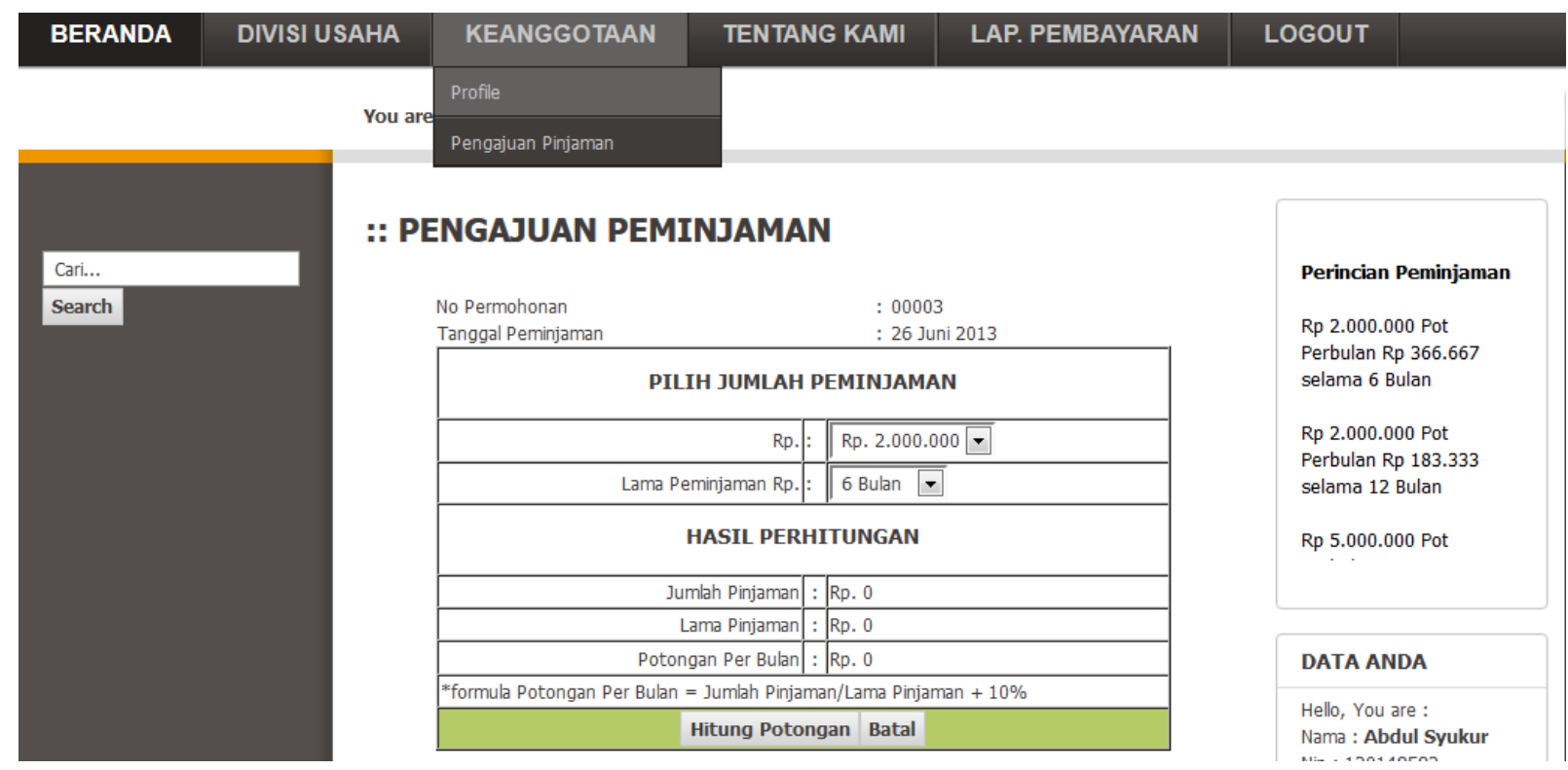

\section{Gambar 13. Tampilan Menu Keanggotaan}

Pada gambar 13 tampilan menu keanggotaan ini digunakan oleh Aggota Koperasi untuk pengajuan peminjaman ke koperasi yang terdiri dari field : pilih jumlah peminjaman, lama pinjaman, hasil perhitungan. Setelah data selesai di input maka anggota mengklik tombol simpan untuk menyimpan data , maka data-data tersebut akan tersimpan didalam database admin dan admin akan mengecek apakah anggota koperasi mendapatkan pinjaman atau tidak.

\section{k. Tampilan Menu Laporan Pembayaran}

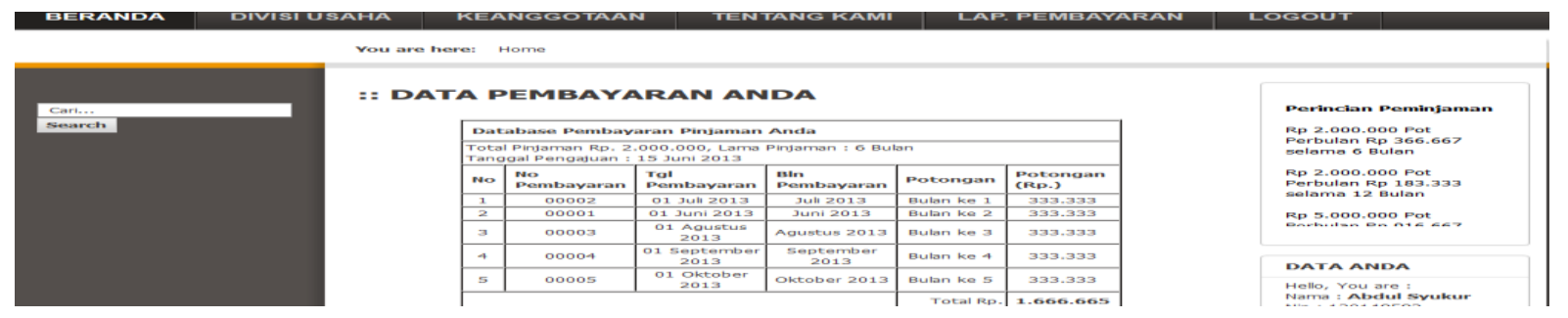

Gambar 14. Tampilan Menu Laporan Pembayaran

Pada gambar 14 tampilan menu laporan pembayaran ini digunakan oleh Aggota Koperasi untuk mengetahui laporan pembayaran yang terdiri dari field : no, no pembayaran, tanggal pembayaran, bln pembayaran, potongan. 


\section{Kesimpulan}

Dilihat dari sistem yang berjalan saat ini dirasa masih kurang baik dikarenakan masih menggunakan sistem manual dengan cara pembuatan laporan menggunakan Microsoft Excel. Sistem yang berjalan belum dapat mengelola data dengan efektif dan efisien, sehingga dapat menyajikan laporan yang diperlukan membutuhkan waktu yang sedikit lama dan kurang akurat.

Dalam membangun program aplikasi simpan pinjam pada koperasi SAMI berbasis WEB diperlukan sistem informasi yang berbasis komputerisasi dengan menggunakan bahasa pemograman seperti PHP Hypertext Preprocessor yaitu bahasa pemrograman web server-side yang bersifat open source, agar dapat menyelesaikan laporan-laporan simpan pinjam koperasi demi terciptanya laporan yang efektif dan efisien.

\section{Daftar Pustaka}

1. Al Fatta, Hanif. 2007. Analisis Dan Perancangan Sistem Informasi. Andi : Yogyakarta.

2. Anhar, Panduan Menguasai PHP Dan MySQL Secara Otodidak, mediakita, Jakarta, 2010

3. Harahap. Hapsah. Fatimah, Agung Gde Agung Anak. "Aplikasi Simpan Pinjam Berbasis Web. Politeknik Telkom Bandung. Indonesia. 2013

4. Maulana. Citra. "Rancang Bangun Informasi Penjualan dan Simpan Pinjam pada Koperasi Pegawai Mahkamah Agung Jakarta” Universitas Gunadarma, Indonesia. 2013.

5. Matcome .2006. Macromedia Dreamweaver 8.Andi : Yogyakarta

6. Nugroho Bunafit.2005. Database Relasional Dengan MySQl. Andi : Yogyakarta

7. Nashir. Muhammad, Riyadi. Ahmad. "Sistem Administrasi Koperasi Simpan Pinjam Kopkar Sejahtera upy menggunakan multi interface" Jurnal Dinamika Informatika. Universitas PGRI Yogyakarta. 2010.

8. Prasetyawan. Agung, Satoto. Kodrat. Iman, Fatchur. Rochim. Adian. "Perancangan Sistem Informasi Simpan Pinjam Koperasi Pegawai Republik Indonesia Universitas Diponegoro Berbasis Web. Universitas Diponegoro. Indonesia. 2013.

9. Wibowo. Edi. " Rancang Bangun Sistem Pengoalahan Data Simpan Pinjam Koperasi”. STMIK AMIKOM Yogyakarta. Indonesia. 2012.

10. Yunita. Ratih, Jemakmun, Tujni Baibul. "Rancang bangun sistem informasi simpan pinjam pada koperasi ganesa indah balai konservasi sumber daya alam (ksda) sum-sel dengan menggunakan metode prototyping” Universitas Bina Darma, Indonesia. 2013. 